\title{
The Role of University in Empowerment of Clean Living for Anticipating the Spread of Covid-19 at East Java
}

\author{
Sri Setyo Iriani ${ }^{1 *}$, Janet Trineke Manoy ${ }^{2}$, Vega Candra Dinata $^{3}$, Irfa Ronaboyd ${ }^{4}$ \\ ${ }^{1}$ Management Department, Faculty of Economic, Universitas Negeri Surabaya \\ ${ }^{2}$ Mathematics Department, Mathematics and Science Faculty, Universitas Negeri Surabaya \\ ${ }^{3}$ Physical Education, Health, and Recreation, Faculty of Sport Sciences, Universitas Negeri Surabaya \\ ${ }^{4}$ Law Department, Faculty of Social Sciences and Law, Universitas Negeri Surabaya \\ *Email: srisetyo@unesa.ac.id
}

\begin{abstract}
Various efforts have been made by people around the world to anticipating the spread of the Coronavirus Diseas 19 (Covid-19) which is now considered very dangerous and deadly in a very fast time. The Indonesian government has made prevention by conducting social distacing to PSBB (large-scale social restrictions), in order to maintain security and comfort. However, these efforts could not be fully successful to stop the corona virus because the death rate was also increasing. Therefore, people must be able to take care of themselves through a healthy and clean lifestyle by diligently washing their hands with soap or hand sanitizer, consuming vitamin $\mathrm{C}$ or even drinking herbs and spices. The need for hand sanitizers is greatly increased but not all level of society are unwilling or unable to buy it, such as Ojol, street vendors, casual laborers, market traders and rural communities. Universitas Negeri Surabaya has a concern to devote itself to making healthy hand sanitizers, and then distributed to target audiences in need in various districts of Malang, Kediri, Jombang, Magetan and Gresik. In addition, the Community Service group are providing an understanding of how clean and healthy lifestyles in a pandemic atmosphere and the danger of the corona virus, it turns out that the public has an enthusiastic impression on the information and feels its benefits.
\end{abstract}

Keywords: Covid-19, Empowerment of Clean living, East Java

\section{INTRODUCTION}

Coronavirus Disease 2019 (Covid-19) has spread in 170 countries with a death rate of $3.64 \%$. [1] This condition has affected various aspects of human life. Various steps have been taken by the government to limit the spread of this virus, such as taking measures to restrict activities, social distance, physical distance to PSBB (large-scale social restrictions).

On the other hand, people are required to be able to take care of themselves by adopting a clean and healthy lifestyle, for example, diligently washing their hands with soap, using hand sanitizers, consuming sufficient Vitamin $\mathrm{C}$, and drinking spices and herbs. However, during a pandemic, these various needs became increasingly scarce and expensive while demand increased. Not all levels of society are willing and able to buy various needs to protect themselves. Moreover, pandemic conditions have an impact on various sectors, especially the public economy.

Moreover, early June in East Java, especially Surabaya, was a critical period because it entered the red and dark red zone status. [2] This indicates a very high Covid-19 infection in the region. This is caused by people who ignore the clean and healthy lifestyle recommended by the government. [3]

This dilemmatic condition has hampered the government's efforts to tackle the spread of the virus. This situation made various parties aware that the government could not do it alone so that it needed the roles of various parties to make this agenda a success, especially universities.

Universities have a strategic role in life, especially as a forum for educating the potential of young 
people. University reflects human civilization through the knowledge and culture of a country. In this relative and critical condition, the university has an important role in assuming responsibility and participating in facing the challenges that exist as evidence of its commitment to serving the community.

Surabaya State University (UNESA) as one of the public universities in East Java has a concern to devote itself to the community during a pandemic. This contribution is through the manufacture of hand sanitizers which are needed by the community to prevent the spread of the virus. This is a form of implementation of science and technology which is the strength of the university. Besides, the university's important role is to provide enthusiasm, trust, and unity in society to jointly face the pandemic.

Along with this, UNESA responded in various ways to help reduce the spread of the virus. However, there are various challenges in its implementation, especially in providing an understanding of a healthy and clean lifestyle to the community. Therefore, this paper is compiled to determine the proper role of the University is participating in suppressing the spread of Covid-19.

\section{METHOD}

The model of community service activities carried out by this team is to make Hand Sanitizers made from chemicals by buying and selecting quality materials and meet the WHO manufacturing standards. Furthermore, this product is packaged in 50 $\mathrm{ml}$ and $100 \mathrm{ml}$ bottles and packaged for all areas of the activity objective.

The mechanism for this community service activity is carried out by: (1) educating the public about the Covid-19 Virus pandemic and its effects (2) distributing Hand Sanitizer products and explaining the function of these products in anticipating the spread of the Covid-19 virus. Before this activity was carried out the team coordinated with the village head, community leaders, and organizational leaders. At the time of their activities, they are gathered in a meeting room while maintaining a distance and implementing health protocols.

The target groups in this activity are people who work as OJOL in the city of Surabaya, community groups who work as traders in traditional markets in Sambi Kediri Village, farmers, and freelancers in the Gresik and Lamongan areas.

\section{RESULTS AND DISCUSSION}

The Covid-19 pandemic is not only a health crisis problem but also a multidimensional problem that affects various aspects globally. The United Nations reports that this pandemic affects all segments of the population and adversely affects members of social groups in the most vulnerable situations, continuing to affect the population, including people living in situations of poverty, the elderly, people with disabilities, youth, and indigenous peoples. [4]

One of the most noticeable aspects of the health crisis is the economy. The Covid-19 pandemic has indirectly affected the reduction in people's productive activities. The application of the PSBB as a government measure to tackle the spread of the virus causes limited community activities. Even so, several activities carry out work activities following the health program, particularly the public transportation sector.

Drivers and public transportation service actors are prone to contracting and transmitting the Covid-19 virus. This is due to their mobility in the field and of course a lot of contact with people. Besides, public areas that are in contact with public transportation modes have a high potential for the spread of Covid19. Purabaya Terminal in Bungurasih, as one of the areas that are crowded with people traveling in and out of the city, is an area prone to spreading the virus. Moreover, around Purabaya Terminal there is a Grab Lounge which is located on Jl. Lt. Gen. Sutoyo, Medaeng, Bungur became a gathering place for drivers. At least, there are about sixty drivers who usually wait for passengers there. This condition was felt necessary to distribute masks and hand sanitizers which were still rare at that time to drivers there.

The use of a hand-sanitizer is very important to promote a healthy and clean lifestyle. Poonam Khetrapal Singh stated that hand hygiene is one of the most basic but powerful tools that must be used to reduce the spread of COVID-19. [5] Also, masks are also a mandatory tool used by people when leaving the house or doing activities outside the home. Unfortunately, both of these items become scarce, and even if there is a price they become expensive.

Indirectly, access to the availability of these two tools is very urgent for the community. Especially the poor who are economically vulnerable. If the head of the family is sick or infected it affects income and family life. On the other hand, not all assets have a selling and salable value. As a result, many families are in debt or unable to meet their daily needs.

\subsection{Role of the University}

In an uncertain situation, UNESA is proactive in helping people who are vulnerable to being affected by Covid-19. This seems natural if we pay attention to the Higher Education Law which requires every 
university to carry out three dharmas: education, research, and community service.

In the context of Covid-19, the roles that universities can play are varied. Education as the foundation of the university has both social and individual dimensions. Through education, various elements of society are given opportunities to develop individual and collective capacities. The role of education in universities has evolved into research. Universities are no longer just educating and increasing the capacity of human resources, but also producing or creating science and technology.

The development of the university's role occurs because of the awareness of the social dimension of the university as part of society with all its problems. Therefore, there is a social responsibility attached to the university to help solve problems faced by society. In this phase, the role of education and research inherent in the university is directed towards community service.

For Schieffer \& Ronnie, four university functions can be integrated, namely education, research, community activation, and Catalysing development. [6] Schieffer \& Ronnie wanted the university's two main functions, education, and research, to be developed and integrated with community activation and catalyzing development. The integration that Schieffer \& Ronnie wants involves other actors because it covers the entire spectrum of individuals, organizations, communities, and societies.

The real role of the university in community activation and catalyzing development can be seen from the empowerment program that is included in the dharma of community service. Amid limitations, the university continues to carry out its social responsibility and is responsive to participating in suppressing the spread of Covid-19. Universities with all their resources do what they can, one of which is through empowering a clean and healthy lifestyle.

\subsection{Empowerment of Clean and Healthy Living}

The concept of empowerment originates from the perception of community powerlessness caused by limiting factors from within and from outside that paralyzes or limit the movement of people to act according to their own will. The final goal to be achieved from empowerment is to form individuals and communities to become independent and participate in the development and solving problems at hand. Independence here means being independent in thinking, acting, and controlling the activities carried out. According to Ginanjar Kartasasmita, the implementation of community empowerment must be carried out through several activities, namely: enabling, empowering, and protecting. [7]

Enabling departs from a framework that sees that every community has potential that can be developed. At this stage, the first thing to do is to create an atmosphere or climate that allows the potential of the community to develop. This can be done by encouraging, motivating, and raising awareness of its potential and trying to develop it.

Next, empowering. This is the phase of strengthening the potential or power possessed by the community (empowering). This strengthening includes concrete steps and involves the provision of various inputs, as well as opportunities that will make society more empowered. So, there needs to be a special program for people who are less empowered because not all programs can be effective and reach all levels of society.

To empower means to protect. In the empowerment process, there must be prevention for the weak from becoming weaker, because of a lack of power in facing the strong. Therefore, protection and partiality for the weak are very basic in the concept of community empowerment. Protecting does not mean isolating or covering up from interactions.

As a first step in empowering a clean and healthy life, UNESA is refocusing the budget. Through the efficiency of several activities whose needs are not urgent and prioritize activities oriented towards handling pandemics. From refocusing the budget, various activities have been carried out.

These various activities include:

1) distribution of necessities to community groups that have a financial impact, such as Unesa students who cannot return to their hometowns, street vendors around campus;

2) the distribution of hazmat or what is known as decontamination clothing / personal protective equipment which consists of impermeable materials and is used for protection against hazardous materials provided to hospitals and other medical personnel;

3) distribution of masks, hand-sanitizers to groups of the general public and the academic community;

4) conduct trauma healing activities with a spiritual approach which is divided into two ways, namely self-healing trauma and mentoring. This activity is primarily aimed at groups of students who come home from Wuhan and their families, but this activity develops in other communities. 
Some of the activities mentioned above are carried out in a coordinated and documented manner within the institution but in practice, they have several limitations, including coordination and stabilization of activities and determination of activity schedules due to government regulations related to social distance and physical distance which require changes in implementation time and group representatives. target.

These obstacles can be overcome through face-toface communication and coordination. An example is the distribution of masks and hand sanitizers. The first thing to do is coordinate with the Grab Lounge manager to ask for permission to distribute masks and hand sanitizers to ojol drivers in that place. Communication and permission were very important to facilitate the team in distributing relief items. Then the relief items were distributed to the online drivers there.

Our arrival was welcomed by the Grab Lounge. Several things make them happy with this assistance. First, masks that are hard to find. Drivers need masks to protect themselves from transmission and infection from viruses. Even though some already have masks, basically they also need a spare mask if the mask they have has to be washed or it's time to be replaced. Second, hand-sanitizer is difficult, and even if there is a price tag. Moreover, the income of online drivers has decreased drastically when pandemic occurred.

Another obstacle that arose when the Grab Lounge manager objected to providing Ojol driver data because it was related to privacy and company policies. This can be overcome by diverting to the more flexible online driver association in Grab Longue. Another obstacle arises when you have to bring in drivers because not all drivers are in the location. It should be noted that there are provisions and recommendations for limiting the number of drivers in the Grab Lounge so that crowds do not occur. Also, public areas are prohibited from becoming places where large numbers of people gather to prevent the spread of the virus and as an effort to break the chain of spread. This condition caused the distribution to take several days, which was originally planned for only one day.

Suggestions in implementing assistance in cases encountered are related to verification by signature. Proof through paper signatures at the time of the pandemic raises concerns for online drivers to be infected or infectious. They have doubts about the cleanliness of their clothes and hands (elbows or arms) after a long time on the road or interacting with many consumers.

\section{CONCLUSIONS}

Universities cannot go alone in suppressing the spread of the virus. Therefore, it is necessary to integrate with various parties in fulfilling and empowering the community during a pandemic. Empowerment in the context of university war reflects the provision of ability or empowerment as well as providing opportunities for other parties to do something independently. Giving masks and hand sanitizers is one way of empowering a clean and healthy lifestyle. Even though they seem trivial, they are very valuable in scarcity and affordability for the poor.

\section{REFERENCES}

[1] Kompas, 2020, “Angka Kematian Akibat Covid-19 di Indonesia masih lebih tinggi dari dunia,

https://www.kompas.tv/article/101098/angka -kematian-akibat-covid-19-di-indonesiamasih-lebih-tinggi-dari-dunia, diakses tanggal 12 Agustus 2020

[2] Kompas.com, "Mengenal Apa itu Zona Hitam Di Surabaya dan Mengapa Bisa Terjadi,"

https://www.kompas.com/tren/read/2020/06/ 03/140712365/mengenal-apa-itu-zona-hitamdi-surabaya-dan-mengapa-bisaterjadi?page $=$ all diakses tanggal 10 Juni 2020.

[3] Ibid. United Nation, "Everyone Included: Social Impact of COVID-19", https://www.un.org/development/desa/dspd/e veryone-included-covid-19.html, diakses 20 Agustus 2020.

[4] Poonam Khetrapal Singh, "Promote hand hygiene to save lives and combat COVID$19, "$

https://www.who.int/southeastasia/news/detai 1/04-05-2020-promote-hand-hygiene-to-savelives-and-combat-covid-19 diakses 10 Juni 2020.

[5] Alexander Schieffer \& Ronnie Lessem, "The Integral University: Holistic individuals, communities, organisations and societies." Prospects (2014) 44: 607-626.

[6] Ginandjar Kartasasmita, Pembangunan Untuk Rakyat: Memadukan Pertumbuhan dan Pemerataan. Jakarta: CIDES, 1996. 